\title{
Anti arthritic potentials of Piper betle- A preclinical study
}

\author{
Karunakar Hegde ${ }^{1, *}$, Aparna Emani², Shrijani J K ${ }^{3}$, A R Shabaraya ${ }^{4}$ \\ ${ }^{1,4}$ Professor, ${ }^{2}$ Assistant Professor, ${ }^{3}$ Scholar, Dept. of Pharmacology, Srinivas College of Pharmacy, Valachil, Post- Farangepete, \\ Mangalore, Karnataka, India
}

*Corresponding Author:

Email: khegde_sh2003@yahoo.co.in

\begin{abstract}
The objective of the recent work was to evaluate the anti-arthritic activity of Piper betle leaves against CFA induced arthritis in rats. Anti-arthritic activity of hydro-alcoholic (1:4) extract of Piper betle leaves was investigated against complete Freund's adjuvant induced arthritis in rats. Two doses $20 \mathrm{~A} 0 \mathrm{mg} / \mathrm{kg}$ and $400 \mathrm{mg} / \mathrm{kg}$ of Piper betle leaves extract (oral route) was subjected for the evaluation of anti-arthritic activity against complete Freund's adjuvant $(0.1 \mathrm{ml}$ sub plantar region) induced arthritis in rats. Diclofenac $(50 \mathrm{mg} / \mathrm{kg}$ oral) was used as standard in both the models (prophylactic \& curative). Physical parameters such as paw volume, paw diameter and body weight were evaluated. Serum parameters such as SGPT, SGOT and ALP, rheumatoid factor were evaluated. In addition histopathological study was also carried out. It was observed in both the models that both the lower dose $(200 \mathrm{mg} / \mathrm{kg})$ and higher dose $(400 \mathrm{mg} / \mathrm{kg})$ of Piper betle extract showed dose dependent significant decrease in SGPT, SGOT, and ALP, paw volume, paw diameter and increase in body weight when compared to arthritic control group. All treated animals showed significant decrease in serum rheumatoid factor. In addition anti-arthritic effect was also confirmed by histopathology of synovial joint showed less space narrowing of inter tarsal joints in treated rats. The results obtained were comparable with that of standard. The present study concluded that hydro-alcoholic extract of Piper betle leaves has significant anti-arthritic potential. The exact mechanism for the anti-arthritic activity of hydro-alcoholic extract of Piper betle is still unknown. Hence further studies are needed to isolate, characterize the active principles and to find out the exact mechanism responsible for its anti-arthritic activity.
\end{abstract}

Keywords: Arthritis, Complete Freund's Adjuvant, Diclofenac, Piper betle, Rheumatoid factor.

\section{Introduction}

Bone loss is a common feature of various inflammatory arthritis disorders .Bone erosions results from the activation of an inflammatory response that increases the number and activity of osteoblasts. ${ }^{1,2}$ Bone erosions and peri-articular osteopenia constitutes an important signs for the diagnosis of rheumatoid arthritis. $^{3}$ Inflammatory diseases including different types of diseases are the major causes of morbidity of the working force throughout world. This is called as "King of Miseries". Inflammation is the local response of the living mammalian tissues to the injury. ${ }^{5}$ It is the complex response in the vascularized connective tissue occurs due to exogenous and endogenous stimuli. ${ }^{6}$ This hyperplasia leads to degeneration of cartilage, erosion of bone and ultimately functional loss of joints. ${ }^{7}$ The major site of irreversible tissue damage originates from synovium lining the joint capsule with cartilage and bone, which is often, termed the "pannus" and this is a characteristic feature of RA.

Though conventional treatment options for this condition have improved in terms of effectiveness, the use of non-steroidal anti-inflammatory drugs (NSAIDs) like etoricoxib, disease modifying anti-rheumatic drugs (DMARDs) like Methotrexate sulphasalazineleflunomide, Hydroxychloroquine, and corticosteroids like Prednisolone, methylprednisolone have all been associated with adverse effects. ${ }^{8}$ However, besides high costs, all of these drugs are associated with numerous side effects, severe adverse reactions and toxicity, including some risk of infections in subsets of patients who are being treated with biological response modifiers. In recent days, researchers are directed towards traditional system of medicine for the discovery of drugs that are long acting anti-inflammatory agents displaying minimum side effects. According to the WHO report, about $70-80 \%$ of the world's population relies on nonconventional medicine mainly from herbal sources in their primary health care. Especially, its demand is increasing day by day in developing countries where the cost of consulting a physician and price of medicine are beyond the limit of most people. ${ }^{9}$

Piper betle is native to Central and Eastern Malaysia and was taken into cultivation for more than 2500 years ago throughout Malaysia and Tropical Asia. It has reached Madagascar and East Africa much later and was introduced in West Indies. Betel leaves chewing was widespread among South China and South India since Europeans arrived in $15^{\text {th }}$ century. ${ }^{10}$ With known ethno medicinal properties, this plant is widely used in India, Indonesia, and other countries of IndoChina region. Betel is widely distributed in all over the state of India except Northern regions due to hot dry summer. From review of literature it is found that the plant contains flavonoids, alkaloids, proteins, tannins and essential oils and it reveals the traditional use of the plant in the treatment many ailments. One such plant is Piper betle leaves. Piper betle leaves is used as carminative, bronchitis, tonic, anthelmentic, stomachic, 
inflammation such as arthritis and orchitis by tribal healers. ${ }^{11}$

The present study was undertaken to evaluate the anti-arthritic activity of hydro-alcoholic extract of Piper betle leaves against complete Freund's adjuvant induced arthritis in rats.

\section{Materials and Methods General methods}

Diclofenac sodium (Yarrow Chem Products), CFA cell suspension. ( Sigma Aldrich), SGPT kit ,SGOT kit ,ALP kit ,Rheumatoid factor kit (Agappe Diagnostic Ltd, Ernakulum).The fresh leaves of Piper betle leaves used for the present studies were collected from local market at Mangalore. The leaves were dried under shade. The dried leaves were pulverized separately into coarse powder by a mechanical grinder and were used for extraction.

\section{Plant material}

The leaves of Piper betle were collected from the local market, Mangalore and its botanical identity was confirmed by M. Dinesh Nayak, Advisor (Sasyashymala) Green belt Urwa stores, Mangalore.

\section{Preparation of hydro-alcoholic extract}

The powdered material was subjected to maceration process. The powdered material $(150 \mathrm{~g})$ is subjected to maceration at room temperature by mixing the ground drug with the solvent (drug solvent ratio: 1:5 or 1:10) and leaving the mixture for several days with occasional shaking or stirring. The extract is then repeated from the plant particles by straining. The process is repeated for once or twice with fresh solvent .Finally the last residue of extract is pressed out of the plant particles using a mechanical press or a centrifuge. The concentrated extract was then air dried at room temperature, weighed and percentage yield was calculated. The colour and consistency of the extract were noted.

\section{Animals}

Studies were carried out by using male albino Wistar rats $(150-300 \mathrm{~g})$. Animals were grouped and housed in polyacrylic cages and kept at ambient temperature $\left(25^{\circ} \mathrm{C} \pm 2^{\circ} \mathrm{C}\right), 60 \pm 5 \%$ relative humidity and $12 \mathrm{~h}$ light and dark cycle. They had been given standard pellet diet (Hindustan Lever Limited, Mumbai, India) and water ad libitum throughout the course of the study. The study protocols were approved by Institutional Animal Ethical Committee (SCP/CPCSEA/F150/P03/2015).

Determination of acute toxicity $\left(\mathrm{LD}_{50}\right)$ of Piper betle Hydro alcoholic of Piper betle leaves was studied for acute toxicity at dose of $2000 \mathrm{mg} / \mathrm{kg}$ by oral route according to OECD guideline No. 425. There was no mortality amongst animals and did not show any toxicity or behavioural changes at dose level $2000 \mathrm{mg} / \mathrm{kg}$. The extract was found to be safe or nontoxic in rats.

\section{Experimental design}

First Set: Complete Freund's adjuvant (CFA) induced arthritis (prophylactic)

Group 1: Vehicle Group

Group 2: Arthritic control (positive control)

Group 3: Diclofenac $(50 \mathrm{mg} / \mathrm{kg})+\mathrm{CFA}$ induced arthritic rats.

Group 4: Piper betle leaves extract (low dose) + CFA induced arthritic rats.

Group 5: Piper betle leaves extract (high dose) + CFA induced arthritic rats.

Male albino Wistar rats (150-200 g) were made arthritic by single sub plantar injection of $0.1 \mathrm{ml}$ of complete Freund's adjuvant (CFA). The drug treatment was started from the initial day i.e. from the day of adjuvant injection (day 0) $30 \mathrm{~min}$ prior to adjuvant administration and continued till $21^{\text {st }}$ day. Paw diameter and paw volume was measured on $0^{\text {th }}, 4^{\text {th }}, 8^{\text {th }}, 14^{\text {th }}$ and $21^{\text {st }}$ day by using plethsymometer and verneir calliper respectively. ${ }^{12}$ The body weight of animals was measured by using digital balance to access the course of the disease at the initial day before induction and at the end of $21^{\text {st }}$ day. The animals were anaesthetized with chloroform and blood sample will be collected by retro orbital puncture for the estimation of serum parameters like Serum glutamic oxidase transaminase (SGOT), Serum glutamic pyruvate transaminase (SGPT), Alanine phosphatase (ALP) and Rheumatoid factor (RF). ${ }^{13}$

Second Set: CFA induced arthritis (curative)

Group 1: Vehicle Group

Group 2: Arthritic control (positive control)

Group 3: Diclofenac $(50 \mathrm{mg} / \mathrm{kg})+C F A$ induced arthritic rats.

Group 4: Piper betle leaves extract (low dose) + CFA induced arthritic rats.

Group 5: Piper betle leaves extract (high dose) + CFA induced arthritic rats.

Male albino adult Wistar rats were taken with initial body weight of 200 to $300 \mathrm{~g}$ and animals were divided into five groups of six animals in each. On the day 0 animals were injected sub plantar region of $0.1 \mathrm{ml}$ of complete Freund's adjuvant in left hind paw. To study the effect of drugs on established arthritis dosing with test and standard will be started from day 7 and will be continued up to $21^{\text {st }}$ days. The degree of inflammation was measured on Plethsymometer on $1^{\text {st }}$, $3^{\text {rd }}, 6^{\text {th }}, 9^{\text {th }}, 13^{\text {th }}, 15^{\text {th }}, 21^{\text {st }}$ days. ${ }^{3}$ The $6^{\text {th }}$ day was the indication of primary lesions ${ }^{14}$ and $13^{\text {th }}$ day helped in estimating secondary lesions. The body weight of animals was measured by using digital balance to access the course of the disease at the initial day before induction and at the end of $21^{\text {st }}$ day. The animals were anaesthetized and blood sample will be collected for the 
estimation of serum parameters similar to set 1 . The percentage inhibition of edema volume was calculated using the following formula. ${ }^{15}$

Percentage inhibition $=\left(1-\mathrm{V}_{\mathrm{t}} / \mathrm{V}_{\mathrm{c}}\right) \times 100$

Where $V_{t}$ and $V_{c}$ are the relative changes in the edema of test and control respectively

\section{Histopathological Studies}

Rats were sacrificed with anaesthesia. Their legs were removed and fixed with $10 \%$ neutral buffered formalin. The tissues were decalcified in 5\% EDTA-2Na solution. The joints will be imbedded in paraffin. The specimens were cut into $6 \mu \mathrm{m}$ sections and stained with haemotoxylin and eosin. ${ }^{16}$

\section{Statistical Analysis}

All data were expressed as Mean \pm SEM. The statistical significance between groups were compared using one way ANOVA, followed by Dunnett's (multiple comparison test)and student t test.

\section{Results and Discussion}

Rheumatoid Arthritis is a common autoimmune disorder, the immunologically mediated CFA induced arthritic model is considered as one of the outstanding animal model of RA. It is characterized by affecting the peripheral joints. As it causes severe cripping deformities it affects mainly the synovial joint. There are 4 phases of arthritis on the basis of biochemical markers of arthritis: 1) Day 1-4 with acute local inflammation and systemic effects (liver); 2) Days 7-12 with remission of acute inflammation and periarthritis; 3) Days 12-28 with chronic inflammation, periarthritis and osteogenic activity; 4) Day 35 onwards (indefinitely) with permanent articular deformity and minimal (burn- out) inflammation. ${ }^{11}$

The hydroalchoholic extract prepared was subjected to phytochemical tests and the outcome of these tests revealed the presence of alkaloids, carbohydrates, proteins, essential oils, tannins and flavonoids.

The present study was carried out to evaluate the efficiency of hydro alcoholic extract of Piper betle leaves against a chronic inflammatory disease i.e. rheumatoid arthritis. In the present study, rats were selected to induce arthritis because they develop a chronic swelling in multiple joints due to accumulation of inflammatory cells, erosion of joint cartilage and bone destruction. It has close similarities to human rheumatoid diseases; the pain is mainly due to accumulation of synovial fluid around synovial membrane leading to bone destruction. The Freund's adjuvant model is one of the finest model to study arthritis affecting various joints. Chronic inflammation involves the release of number of mediators like cytokines (IL-1B and TNF-alpha), GM-CSF, interferon's and PGDF. These mediators are responsible for the pain, destruction of bone and cartilage that can lead to severe disability. ${ }^{13}$

In present prophylactic study animals treated with PBHE $(200 \mathrm{mg} / \mathrm{kg})$ showed decrease in paw edema with percentage inhibition on the Day $8(10.52 \%)$, Day 14 $(19.56 \%)$ and Day $21(37.71 \%)$ when compared to arthritic control group with $\mathrm{P}<0.05$, whereas animals treated with PBHE $(400 \mathrm{mg} / \mathrm{kg})$ showed decrease in paw edema with \% inhibition on Day $8(27.63 \%)$, day 14 (42.39\% and Day $21(59.64 \%)$ when compared to arthritic control group with $\mathrm{P}<0.01$. (Table 1)

Animals those which received Diclofenac $(50 \mathrm{mg} / \mathrm{kg})$ showed reduction in paw diameter on days 8,14 and 21 when compared to arthritic control with $\mathrm{P}<$ 0.001. Animals receiving PBHE $(200 \mathrm{mg} / \mathrm{kg})$ showed decrease in paw diameter on Days 8, 14 and 21 when compared to arthritic control with $\mathrm{P}<0.05$, whereas animals received PBHE $(400 \mathrm{mg} / \mathrm{kg})$ showed decrease in paw diameter on Days 8, 9 and 21 when compared to arthritic control with $\mathrm{P}<0.01$. (Table 2)

In curative study of arthritis animals which received PBHE $(200 \mathrm{mg} / \mathrm{kg})$ showed decrease in paw edema on Day $9(10.75 \%)$, Day $13(23.71 \%)$, Day 15 $(37.16 \%)$ and Day $21(43.90 \%)$ when compared to arthritic control with $\mathrm{P}<0.05$, whereas animals received PBHE $(400 \mathrm{mg} / \mathrm{kg}$ ) showed decrease in paw edema on Day 9 (18.27\%), Day 13 (30.92\%), Day 15 (45.13\%) and Day $21(52.84 \%)$ when compared to arthritic control with $\mathrm{P}<0.01$ respectively. (Table 3 )

Animals received Diclofenac $(50 \mathrm{mg} / \mathrm{kg})$ showed decrease in paw diameter on Days 9, 13, 15 and 21 when compared to arthritic control with $\mathrm{P}<0.001$. Animals treated with PBHE (200mg/kg) showed decrease in paw diameter on Days 9, 13, 15 and 21 when compared to arthritic control with $\mathrm{P}<0.05$, whereas animals received PBHE $(400 \mathrm{mg} / \mathrm{kg}$ ) showed decrease in paw diameter on Days 9, 13, 15 and 21 when compared to arthritic control with $\mathrm{P}<0.01$ respectively. (Table 4)

The incidence and severity of arthritis increased the changes in the body weight of the rats in both models. (Table 6) Earlier findings suggest that changes in body weight during arthritic inflammation are due to alteration in metabolic activities of rats and also due to reduced absorption of glucose and leucine in rat intestine. In addition to this decreased food intake due to partial immobility accompanying hyperalgesia may also be one of the reasons. But on the treatment with anti-inflammatory drugs, the decrease in absorption was nullified and it shows that the anti-inflammatory drugs correct the decreased/deranged absorption capacity of intestine during inflammation. The increased body weight during treatment of standard drug, prophylactic and curative effect of Hydro alcoholic extracts of Piper betle leaves may be due to the restoration of absorption capacity of intestine.

The activities of SGOT, SGPT and ALP increases significantly in arthritic rats, since these are good 
parameters to study if any damage or injury has occurred to the liver as liver toxicity is the potential side effect of arthritis medications. Administration of CFA causes disruption of hepatocytes, bone destruction, cartilage etc. ${ }^{11}$ Elevated levels of serum ALP in CFA induced arthritic rats may be due to localized bone loss in the form of bone erosion and periarticular osteopenia. PBHE $(200 \mathrm{mg} / \mathrm{kg})$ and PBHE $(400 \mathrm{mg} / \mathrm{kg})$ also showed significant effect on these serum biochemical parameters.

Rheumatoid factor is protein normally produced by the immune system that will attack the healthy tissue in body. Generally in healthy individuals our body do not produce RF but presence of RF indicates autoimmune disorders. Higher the levels of serum rheumatoid factor, higher are the development of inflammation. ${ }^{3}$ Serum rheumatoid factor (RF) measures the amount of antibody IgM titer present in the serum. Standard and Piper betle leaves extract treated animals showed significantly lesser serum RF when compared to disease control animals.

In prophylactic study administration of Diclofenac $(50 \mathrm{mg} / \mathrm{kg})$ showed decrease in SGPT, SGOT and ALP levels when compared to arthritic control group with $\mathrm{P}<0.001$.

Administration of PBHE $(200 \mathrm{mg} / \mathrm{kg})$ showed decrease in SGPT, SGOT and ALP levels when compared to arthritic control with $\mathrm{P}<0.05$ whereas administration of PBHE $(400 \mathrm{mg} / \mathrm{kg})$ showed decrease in SGOT, SGPT and ALP when compared to arthritic control with $\mathrm{P}<0.001$ respectively. Arthritic control animals showed increase in agglutination with increase in RF values when compared to treated group of PBHE $(200 \mathrm{mg} / \mathrm{kg})$ and PBHE $(400 \mathrm{mg} / \mathrm{kg})$ and standard $(50 \mathrm{mg} / \mathrm{kg}$ ) respectively. (Table 5)

In curative study administration of Diclofenac $(50 \mathrm{mg} / \mathrm{kg})$ showed decrease in SGPT, SGOT and ALP levels when compared to arthritic control group with $\mathrm{P}<0.001$. Arthritic control animals showed increase in agglutination with increase in RF values when compared to treated group of PBHE $(200 \mathrm{mg} / \mathrm{kg})$ and PBHE $(400 \mathrm{mg} / \mathrm{kg})$ and standard $(50 \mathrm{mg} / \mathrm{kg})$ respectively. Administration of low dose $(200 \mathrm{mg} / \mathrm{kg})$ showed decrease in SGPT, SGOT and ALP levels when compared to arthritic control with $\mathrm{P}<0.05$ whereas administration of PBHE $(400 \mathrm{mg} / \mathrm{kg})$ showed decrease in SGOT, SGPT and ALP when compared to arthritic control with $\mathrm{P}<0.001$ respectively. (Table 5)

Histopathological studies of synovial joint, treated with diclofenac alone showed significant protection with mild lymphocytic infiltration with no evidence of thickening of synovial lining and angiogenesis, whereas treatment with PBHE $(200 \mathrm{mg} / \mathrm{kg}$ and $400 \mathrm{mg} / \mathrm{kg}$ ) showed milder lymphocytic infiltration with no evidence of thickening of synovial lining and angiogenesis. (Fig. 1) This support the protective effect of Piper betle leaves extract on curative and prophylactic arthritis.

Prophylactic effect of hydro alcoholic extract of Piper betle leaves showed better results by decrease in paw edema, paw diameter, along with serum parameters and serum RF when compared to curative effect of hydro alcoholic extract of Piper betle leaves. (Fig. 2)

Table 1: Prophylactic effect of hydroalchoholic extract of Piper betle leaves against CFA induced arthritic paw edema in rats

\begin{tabular}{|c|c|c|c|c|c|c|}
\hline Groups & $\begin{array}{c}\text { Dose } \\
\text { (mg/kg } \\
\text { b.w, p.o })\end{array}$ & $\mathbf{0 ~ d a y}$ & $\mathbf{4}$ day & $\mathbf{8 ~ d a y}$ & $\mathbf{1 4}$ day & $\mathbf{2 1 ~ d a y}$ \\
\hline Normal & - & $0.22 \pm 0.04$ & $0.23 \pm 0.04$ & $0.24 \pm 0.05$ & $0.22 \pm 0.05$ & $0.23 \pm 0.05$ \\
\hline $\begin{array}{c}\text { Arthritis } \\
\text { control }\end{array}$ & $\begin{array}{c}0.1 \mathrm{ml} \\
\text { CFA }\end{array}$ & $0.28 \pm 0.03$ & $0.65 \pm 0.02$ & $0.76 \pm 0.04$ & $0.92 \pm 0.02$ & $1.14 \pm 0.04$ \\
\hline Diclofenac & 50 & $0.23 \pm 0.04$ & $\begin{array}{c}0.50 \pm 0.04^{* * *} \\
(23.07)\end{array}$ & $\begin{array}{c}0.47 \pm 0.04 * * * \\
(38.15)\end{array}$ & $\begin{array}{c}0.44 \pm 0.06^{* * *} \\
(52.17)\end{array}$ & $\begin{array}{c}0.34 \pm 0.07 * * * \\
(70.17)\end{array}$ \\
\hline PBHE & 100 & $0.24 \pm 0.05$ & $\begin{array}{c}0.64 \pm 0.04^{*} \\
(1.51)\end{array}$ & $\begin{array}{c}0.74 \pm 0.05^{*} \\
(2.63)\end{array}$ & $\begin{array}{c}0.67 \pm 0.03^{*} \\
(27.17)\end{array}$ & $\begin{array}{c}0.60 \pm 0.05^{*} \\
(47.36)\end{array}$ \\
\hline PBHE & 200 & $0.26 \pm 0.05$ & $\begin{array}{c}0.62 \pm 0.05^{*} \\
(4.61)\end{array}$ & $\begin{array}{c}0.60 \pm 0.02^{*} \\
(10.52)\end{array}$ & $\begin{array}{c}0.58 \pm 0.06^{*} \\
(19.56)\end{array}$ & $\begin{array}{c}0.55 \pm 0.02^{*} \\
(37.71)\end{array}$ \\
\hline PBHE & 400 & $0.24 \pm 0.06$ & $\begin{array}{c}0.58 \pm 0.04^{*} \\
(12.06)\end{array}$ & $\begin{array}{c}0.55 \pm 0.04^{* *} \\
(27.63)\end{array}$ & $\begin{array}{c}0.53 \pm 0.06^{* *} \\
(42.39)\end{array}$ & $\begin{array}{c}0.46 \pm 0.07 * * \\
(59.64)\end{array}$ \\
\hline
\end{tabular}

All the results are expressed in term of mean \pm SEM $n=6$ animals in each group; number in parenthesis indicates percentage in inhibition increase in paw volume. Statistical significance was determined by ANOVA followed by dunnet's test. $* \mathrm{P}<0.05,{ }^{*} \mathrm{P}<0.01,{ }^{*} * \mathrm{P}<0.001$, statistically significant compared to arthritic control group. 
Table 2: Effect of Prophylactic study on paw diameter of Piper betle leaves against CFA induced arthritis in rats

\begin{tabular}{|c|c|c|c|c|c|c|}
\hline Groups & $\begin{array}{c}\text { Dose } \\
\text { (mg/kg b.w, p.o) }\end{array}$ & $\mathbf{0 ~ d a y}$ & $\mathbf{4}$ day & $\mathbf{8}$ day & $\mathbf{1 4}$ day & $\mathbf{2 1 ~ d a y ~}$ \\
\hline Normal & - & $5.38 \pm 0.14$ & $5.39 \pm 0.15$ & $5.37 \pm 0.14$ & $5.37 \pm 0.14$ & $5.37 \pm 0.14$ \\
\hline $\begin{array}{c}\text { Arthritis } \\
\text { control }\end{array}$ & $0.1 \mathrm{ml} \mathrm{CFA}$ & $7.55 \pm 0.36$ & $16.24 \pm 0.14$ & $17.50 \pm 0.76$ & $20.67 \pm 1.02$ & $27.50 \pm 1.39$ \\
\hline Diclofenac & 50 & $5.15 \pm 0.44$ & $10.66 \pm 1.05$ & $9.50 \pm 1.05^{* * *}$ & $8.23 \pm 1.02^{* * *}$ & $6.12 \pm 0.70^{* * *}$ \\
\hline PBHE & 100 & $6.00 \pm 0.34$ & $15.13 \pm 1.16$ & $13.05 \pm 0.12^{*}$ & $12.13 \pm 1.08^{*}$ & $11.15 \pm 1.14 *$ \\
\hline PBHE & 200 & $6.12 \pm 0.25$ & $14.67 \pm 1.28$ & $13.23 \pm 1.06^{*}$ & $11.21 \pm 0.70^{*}$ & $9.12 \pm 0.93^{*}$ \\
\hline PBHE & 400 & $5.75 \pm 0.25$ & $12.42 \pm 1.21$ & $10.67 \pm 1.43^{* *}$ & $8.67 \pm 0.88^{* *}$ & $7.21 \pm 0.63^{* *}$ \\
\hline
\end{tabular}

All the results are expressed in term of mean \pm SEM $n=6$ animals in each group. Statistical significance was determined by ANOVA followed by dunnet's test. ${ }^{*} \mathrm{P}<0.05,{ }^{*} * \mathrm{P}<0.01,{ }^{*} * * \mathrm{P}<0.001$, statistically significant compared to arthritic control group.

Table 3: Curative effect of hydroalchoholic extract of Piper betle leaves against CFA induced arthritic paw edema in rats

\begin{tabular}{|c|c|c|c|c|c|c|c|c|}
\hline Groups & $\begin{array}{c}\text { Dose } \\
(\mathrm{mg} / \mathrm{kg} \\
\text { b.w, p.o) }\end{array}$ & 0 day & 3 day & 6 day & 9 day & 13 day & 15 day & 21 day \\
\hline Normal & - & $\begin{array}{l}0.125 \\
\pm 0.06\end{array}$ & $\begin{array}{l}0.127 \\
\pm 0.03\end{array}$ & $\begin{array}{l}0.125 \\
\pm 0.03\end{array}$ & $\begin{array}{l}0.124 \\
\pm 0.03\end{array}$ & $\begin{array}{l}0.125 \\
\pm 0.03\end{array}$ & $\begin{array}{l}0.126 \\
\pm 0.03\end{array}$ & $\begin{array}{l}0.127 \\
\pm 0.03\end{array}$ \\
\hline $\begin{array}{l}\text { Arthritis } \\
\text { control }\end{array}$ & $\begin{array}{l}0.1 \mathrm{ml} \\
\text { CFA }\end{array}$ & $\begin{array}{l}0.130 \\
\pm 0.08\end{array}$ & $\begin{array}{c}0.87 \\
\pm 0.06\end{array}$ & $\begin{array}{c}0.90 \\
\pm 0.05\end{array}$ & $\begin{array}{c}0.93 \\
\pm 0.03\end{array}$ & $\begin{array}{c}0.97 \\
\pm 0.03\end{array}$ & $\begin{array}{c}1.13 \\
\pm 0.03\end{array}$ & $\begin{array}{c}1.23 \\
\pm 0.06\end{array}$ \\
\hline Diclofenac & 50 & $\begin{array}{c}0.126 \\
\pm 0.011\end{array}$ & $\begin{array}{c}0.78 \\
\pm 0.05\end{array}$ & $\begin{array}{c}0.75 \\
\pm 0.05\end{array}$ & $\begin{array}{c}0.73 \\
\pm 0.01^{* * * *} \\
(21.50)\end{array}$ & $\begin{array}{c}0.62 \\
\pm 0.02^{* * * *} \\
(36.08)\end{array}$ & $\begin{array}{c}0.58 \\
\pm 0.012^{* * *} \\
(48.67)\end{array}$ & $\begin{array}{c}0.42 \\
\pm 0.05^{\text {**** }} \\
(65.85)\end{array}$ \\
\hline PBHE & 100 & $\begin{array}{c}0.125 \\
\pm 0.023\end{array}$ & $\begin{array}{c}0.90 \\
\pm 0.024\end{array}$ & $\begin{array}{c}0.89 \\
\pm 0.04\end{array}$ & $\begin{array}{c}0.85 \\
\pm 0.02 * \\
(10.75)\end{array}$ & $\begin{array}{c}0.78 \\
\pm 0.04^{*} \\
(23.71)\end{array}$ & $\begin{array}{c}0.73 \\
\pm 0.02 * \\
(35.39)\end{array}$ & $\begin{array}{c}0.71 \\
\pm 0.04 * \\
(42.27)\end{array}$ \\
\hline PBHE & 200 & $\begin{array}{c}0.128 \\
\pm 0.024\end{array}$ & $\begin{array}{c}0.88 \\
\pm 0.04\end{array}$ & $\begin{array}{c}0.86 \\
\pm 0.03\end{array}$ & $\begin{array}{c}0.83 \\
\pm 0.03^{*} \\
(10.75)\end{array}$ & $\begin{array}{c}0.74 \\
\pm 0.03 * \\
(23.71)\end{array}$ & $\begin{array}{c}0.71 \\
\pm 0.03 * \\
(37.16)\end{array}$ & $\begin{array}{c}0.69 \\
\pm 0.05 * \\
(43.90)\end{array}$ \\
\hline PBHE & 400 & $\begin{array}{l}0.124 \\
\pm 0.11\end{array}$ & $\begin{array}{c}0.81 \\
\pm 0.05\end{array}$ & $\begin{array}{c}0.79 \\
\pm 0.01\end{array}$ & $\begin{array}{c}0.76 \\
\pm 0.02^{* *} \\
(18.27)\end{array}$ & $\begin{array}{c}0.67 \\
\pm 0.01 \text { ** } \\
(30.92)\end{array}$ & $\begin{array}{c}0.62 \\
\pm 0.05^{* *} \\
(45.13)\end{array}$ & $\begin{array}{c}0.58 \\
\pm 0.01 * * \\
(52.84)\end{array}$ \\
\hline
\end{tabular}

All the results are expressed in term of mean \pm SEM $n=6$ animals in each group; number in parenthesis indicates percentage in inhibition increase in paw volume. Statistical significance was determined by ANOVA followed by dunnet's test. $* \mathrm{P}<0.05,{ }^{*} \mathrm{P}<0.01, * * * \mathrm{P}<0.001$, statistically significant compared to arthritic control group.

Table 4: Effect of Curative study on paw diameter of Piper betle leaves against CFA induced arthritis in rats

\begin{tabular}{|c|c|c|c|c|c|c|c|c|}
\hline Groups & $\begin{array}{c}\text { Dose } \\
(\mathrm{mg} / \mathrm{kg} \\
\text { b.w, p.o) }\end{array}$ & 0 day & 3 day & 6 day & 9 day & 13 day & 15 day & 21 day \\
\hline Normal & - & $\begin{array}{c}8.11 \pm \\
0.12\end{array}$ & $\begin{array}{c}8.11 \pm \\
0.12\end{array}$ & $\begin{array}{c}8.12 \pm \\
0.13\end{array}$ & $\begin{array}{c}8.13 \pm \\
0.12\end{array}$ & $\begin{array}{c}8.11 \pm \\
0.11\end{array}$ & $\begin{array}{c}8.11 \pm \\
0.11\end{array}$ & $\begin{array}{c}8.12 \pm \\
0.11\end{array}$ \\
\hline $\begin{array}{l}\text { Arthritis } \\
\text { control }\end{array}$ & $\begin{array}{l}0.1 \mathrm{ml} \\
\text { CFA }\end{array}$ & $\begin{array}{c}12.56 \pm \\
0.12\end{array}$ & $\begin{array}{c}17.25 \pm \\
0.13\end{array}$ & $\begin{array}{c}18.00 \pm \\
0.47\end{array}$ & $\begin{array}{c}21.00 \pm \\
0.53\end{array}$ & $\begin{array}{c}22.00 \pm \\
0.67\end{array}$ & $\begin{array}{c}24.40 \pm \\
0.65\end{array}$ & $\begin{array}{c}26.00 \pm \\
0.54\end{array}$ \\
\hline Diclofenac & 50 & $\begin{array}{c}9.32 \pm \\
0.47\end{array}$ & $\begin{array}{c}15.01 \pm \\
0.14\end{array}$ & $\begin{array}{c}15.94 \pm \\
0.13\end{array}$ & $\begin{array}{l}14.13 \pm \\
0.12 * * *\end{array}$ & $\begin{array}{r}13.14 \pm \\
0.13^{* * * *}\end{array}$ & $\begin{array}{l}12.15 \pm \\
0.14 * * *\end{array}$ & $\begin{array}{r}10.32 \pm \\
0.13 * * *\end{array}$ \\
\hline PBHE & 100 & $\begin{array}{c}12.12 \pm \\
0.13\end{array}$ & $\begin{array}{c}19.14 \pm \\
0.14\end{array}$ & $\begin{array}{c}19.43 \pm \\
0.54\end{array}$ & $\begin{array}{c}18.78 \pm \\
0.74 *\end{array}$ & $\begin{array}{c}17.25 \pm \\
0.46^{*}\end{array}$ & $\begin{array}{c}16.97 \pm \\
0.38^{*}\end{array}$ & $\begin{array}{c}14.01 \pm \\
0.21^{*}\end{array}$ \\
\hline
\end{tabular}




\begin{tabular}{|c|c|c|c|c|c|c|c|c|}
\hline \multirow{2}{*}{ PBHE } & \multirow{2}{*}{200} & $\begin{array}{c}11.23 \pm \\
0.12\end{array}$ & $\begin{array}{c}18.12 \pm \\
0.52\end{array}$ & $\begin{array}{c}17.47 \pm \\
0.55\end{array}$ & $\begin{array}{c}16.67 \pm \\
0.67 *\end{array}$ & $\begin{array}{c}15.23 \pm \\
0.45^{*}\end{array}$ & $\begin{array}{c}14.87 \pm \\
0.35^{*}\end{array}$ & $\begin{array}{c}13.03 \pm \\
0.21^{*}\end{array}$ \\
\hline \multirow{2}{*}{ PBHE } & \multirow{2}{*}{400} & $\begin{array}{c}10.47 \pm \\
0.55\end{array}$ & $\begin{array}{c}16.13 \pm \\
0.12\end{array}$ & $\begin{array}{c}14.47 \pm \\
0.15\end{array}$ & $\begin{array}{c}13.67 \pm \\
0.12 * *\end{array}$ & $\begin{array}{c}12.83 \pm \\
0.74 * *\end{array}$ & $\begin{array}{c}12.07 \pm \\
0.5 * *\end{array}$ & $\begin{array}{c}11.12 \pm \\
0.23 * *\end{array}$ \\
\hline
\end{tabular}

All the results are expressed in term of mean \pm SEM $n=6$ animals in each group. Statistical significance was determined by ANOVA followed by dunnet's test. ${ }^{*} \mathrm{P}<0.05,{ }^{*} * \mathrm{P}<0.01,{ }^{*} * * \mathrm{P}<0.001$, statistically significant compared to arthritic control group.

Table 5: Effect of Prophylactic and Curative study on serum parameters of Piper betle leaves against CFA induced arthritis in rats

\begin{tabular}{|c|c|c|c|c|c|c|c|c|c|}
\hline \multirow[t]{2}{*}{ Groups } & \multirow{2}{*}{$\begin{array}{c}\text { Dose } \\
(\mathrm{mg} / \mathrm{kg} \\
\text { b.w, } \\
\text { p.o) }\end{array}$} & \multicolumn{4}{|c|}{ Prophylactic Group } & \multicolumn{4}{|c|}{ Curative Group } \\
\hline & & $\begin{array}{c}\text { SGOT } \\
\text { (IU/ml) }\end{array}$ & $\begin{array}{c}\text { SGPT } \\
(\text { IU/ml) }\end{array}$ & $\begin{array}{c}\text { ALP } \\
(\mathbf{I U} / \mathbf{m l})\end{array}$ & $\begin{array}{c}\mathbf{R F} \\
(\mathbf{I U} / \mathbf{m l})\end{array}$ & $\begin{array}{c}\text { SGOT } \\
(\text { IU/ml) }\end{array}$ & $\begin{array}{c}\text { SGPT } \\
\text { (IU/ml) }\end{array}$ & $\begin{array}{c}\text { ALP } \\
\text { (IU/ml) }\end{array}$ & $\begin{array}{c}\mathbf{R F} \\
(\mathbf{I U} / \mathbf{m l})\end{array}$ \\
\hline Normal & - & $\begin{array}{c}45.1 \pm \\
2.18\end{array}$ & $\begin{array}{c}49.50 \pm \\
1.44\end{array}$ & $\begin{array}{l}124.37 \\
\pm 0.01\end{array}$ & $\begin{array}{c}8.25 \pm \\
0.57\end{array}$ & $\begin{array}{c}46.16 \pm \\
3.14\end{array}$ & $\begin{array}{c}54.23 \pm \\
1.44\end{array}$ & $\begin{array}{c}143.16 \pm \\
0.12\end{array}$ & $\begin{array}{c}8.34 \pm \\
0.67\end{array}$ \\
\hline $\begin{array}{l}\text { Arthritis } \\
\text { control }\end{array}$ & $\begin{array}{l}0.1 \mathrm{ml} \\
\mathrm{CFA}\end{array}$ & $\begin{array}{c}107.67 \pm \\
2.13\end{array}$ & $\begin{array}{c}93.70 \pm \\
2.87\end{array}$ & $\begin{array}{l}254.28 \\
\pm 3.42\end{array}$ & $\begin{array}{c}47.34 \pm \\
3.36\end{array}$ & $\begin{array}{c}123.32 \\
\pm \\
2.14\end{array}$ & $\begin{array}{c}132.13 \pm \\
2.56\end{array}$ & $\begin{array}{l}276 \pm \\
3.14\end{array}$ & $\begin{array}{c}51.23 \pm \\
0.45\end{array}$ \\
\hline Diclofenac & 50 & $\begin{array}{l}61.10 \pm \\
2.14^{* * * *}\end{array}$ & $\begin{array}{l}72.48 \pm \\
2.09^{* * * *}\end{array}$ & $\begin{array}{l}143.72 \\
\pm 3.9^{* * * *}\end{array}$ & $\begin{array}{l}10.34 \pm \\
2.13^{* *}\end{array}$ & $\begin{array}{l}75.17 \pm \\
2.19^{* * *}\end{array}$ & $\begin{array}{l}67.14 \pm \\
2.14^{* * * *}\end{array}$ & $\begin{array}{c}115.15 \pm \\
1.24^{* * *}\end{array}$ & $\begin{array}{l}23.14 \pm \\
0.32^{* * *}\end{array}$ \\
\hline PBHE & 100 & $\begin{array}{c}101.12 \pm \\
1.12 *\end{array}$ & $\begin{array}{l}98.12 \pm \\
2.12^{*}\end{array}$ & $\begin{array}{c}198.0 \pm \\
2.12^{*}\end{array}$ & $\begin{array}{c}15.12 \pm \\
0.91 *\end{array}$ & $\begin{array}{l}109.0 \pm \\
2.14^{*}\end{array}$ & $\begin{array}{c}115.21 \pm \\
2.14^{*}\end{array}$ & $\begin{array}{c}135.15 \pm \\
1.36^{*}\end{array}$ & $\begin{array}{l}46.16 \pm \\
0.16^{*}\end{array}$ \\
\hline PBHE & 200 & $\begin{array}{c}97.12 \pm \\
2.5^{*} \\
\end{array}$ & $\begin{array}{c}87.39 \pm \\
1.88^{*} \\
\end{array}$ & $\begin{array}{l}196.0 \pm \\
3.23^{* *}\end{array}$ & $\begin{array}{c}14.26 \pm \\
0.85^{*} \\
\end{array}$ & $\begin{array}{c}105.0 \pm \\
2.04^{*}\end{array}$ & $\begin{array}{c}112.32 \pm \\
2.13^{*}\end{array}$ & $\begin{array}{c}132.12 \pm \\
1.35^{*}\end{array}$ & $\begin{array}{c}45.16 \pm \\
0.15^{*}\end{array}$ \\
\hline PBHE & 400 & $\begin{array}{l}86.62 \pm \\
2.04^{* * * *}\end{array}$ & $\begin{array}{l}79.55 \pm \\
2.77^{* * * *} \\
\end{array}$ & $\begin{array}{l}175.0 \pm \\
3.67^{* * * *}\end{array}$ & $\begin{array}{l}12.23 \pm \\
0.43^{* *}\end{array}$ & $\begin{array}{l}98.0 \pm \\
2.12^{* * *}\end{array}$ & $\begin{array}{l}89.12 \pm \\
2.14^{* *} \\
\end{array}$ & $\begin{array}{c}123.14 \pm \\
1.23^{*} \\
\end{array}$ & $\begin{array}{l}32.12 \pm \\
0.16^{*}\end{array}$ \\
\hline
\end{tabular}

All the results are expressed in term of mean \pm SEM $n=6$ animals in each group statistical significance was determined by ANOVA followed by dunnet's test. ${ }^{*} \mathrm{P}<0.05,{ }^{*} \mathrm{P}<0.01,{ }^{*} * * \mathrm{P}<0.001$, statistically significant compared to arthritic control group.

Table 6: Effect of Prophylactic and Curative study of Piper betle leaves on body weight

\begin{tabular}{|c|c|c|c|c|c|}
\hline \multirow[t]{2}{*}{ Groups } & \multirow{2}{*}{$\begin{array}{c}\text { Dose } \\
\text { (mg/kg b.w, p.o) }\end{array}$} & \multicolumn{2}{|c|}{ Prophylactic Group (g) } & \multicolumn{2}{|c|}{ Curative Group (g) } \\
\hline & & $\begin{array}{c}\text { Before } \\
\text { induction }\end{array}$ & On $21^{\text {st }}$ day & $\begin{array}{c}\text { Before } \\
\text { induction }\end{array}$ & On $21^{\text {st }}$ day \\
\hline Normal & - & $165.67 \pm 7.8$ & $198.23 \pm 6.2$ & $186.67 \pm 6.7$ & $216.10 \pm 6.9$ \\
\hline $\begin{array}{l}\text { Arthritis } \\
\text { control }\end{array}$ & $0.1 \mathrm{ml} \mathrm{CFA}$ & $165 \pm 3.13$ & $147.14 \pm 2.18$ & $187.81 \pm 2.1$ & $147.50 \pm 2.14$ \\
\hline Diclofenac & 50 & $165 \pm 2.24$ & $179.12 \pm 1.38 * * *$ & $186.22 \pm 2.12$ & $189.54 \pm 2.00 * * *$ \\
\hline PBHE & 100 & $167 \pm 1.13$ & $182.14 \pm 1.43^{*}$ & $187.24 \pm 2.15$ & $172.21 \pm 3.4^{*}$ \\
\hline PBHE & 200 & $167 \pm 1.12$ & $156.14 \pm 3.21 *$ & $185.23 \pm 2.23$ & $170.33 \pm 3.2 *$ \\
\hline PBHE & 400 & $163.34 \pm 3.15$ & $175.13 \pm 5.17 * *$ & $187.66 \pm 2.1$ & $181.32 \pm 2.98 * *$ \\
\hline
\end{tabular}

Values are expressed as mean \pm SEM $(\mathrm{n}=6),{ }^{*} \mathrm{P}<0.05, * * \mathrm{P}<0.01$, $* * * \mathrm{P}<0.001$ as compared with control followed by Student's t- test. 

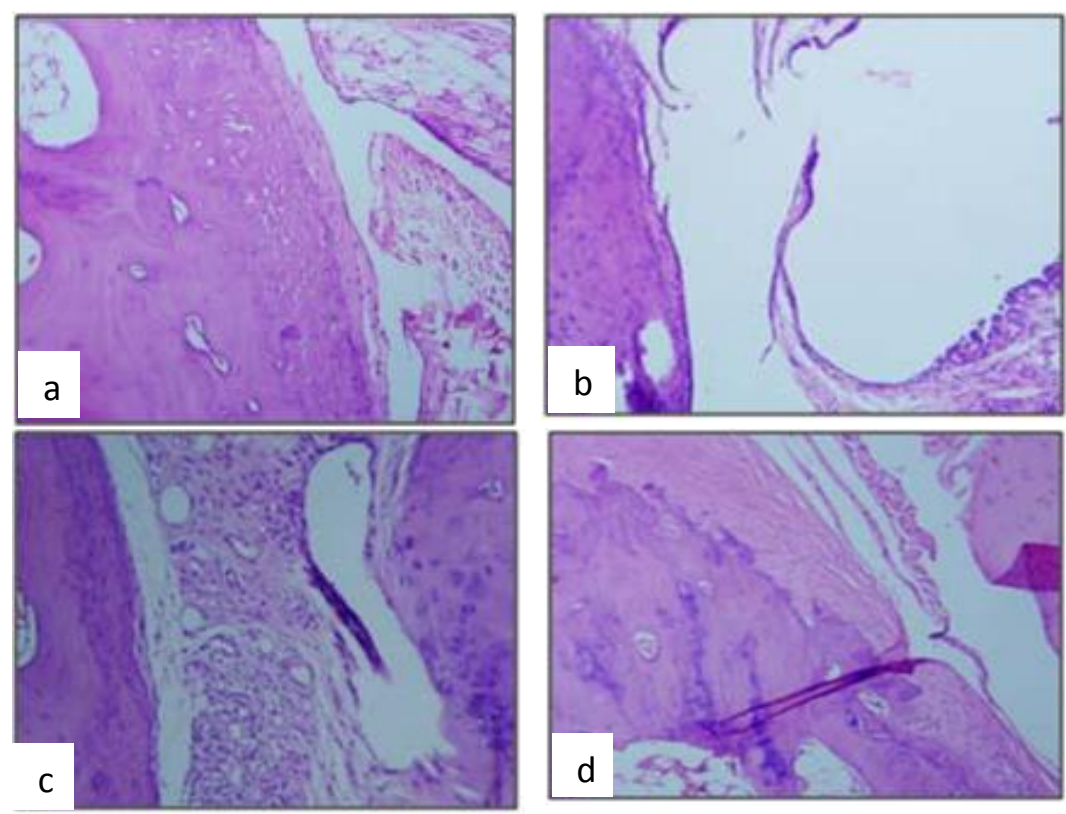

Fig. 1: a. Normal with intact morphology of synovium and synovial lining. b. arthritic control, FA induced disease control rat the arrow mark showed plenty of lymphocytic infiltration in synovial lining with severe inflammation and marked angiogenesis studied with proliferation of synovial cells; c. Diclofenac treated $b(50 \mathrm{mg} / \mathrm{kg})$ arrow mark showed significant protection with mild lymphocytic infiltration with no evidence of thickening of synovial lining and angiogenesis; d. Piper betle leaves extract high dose treated $(400 \mathrm{mg} / \mathrm{kg})$ the arrow mark showed milder lymphocytic infiltration with no evidence of thickening of synovial lining and angiogenesis
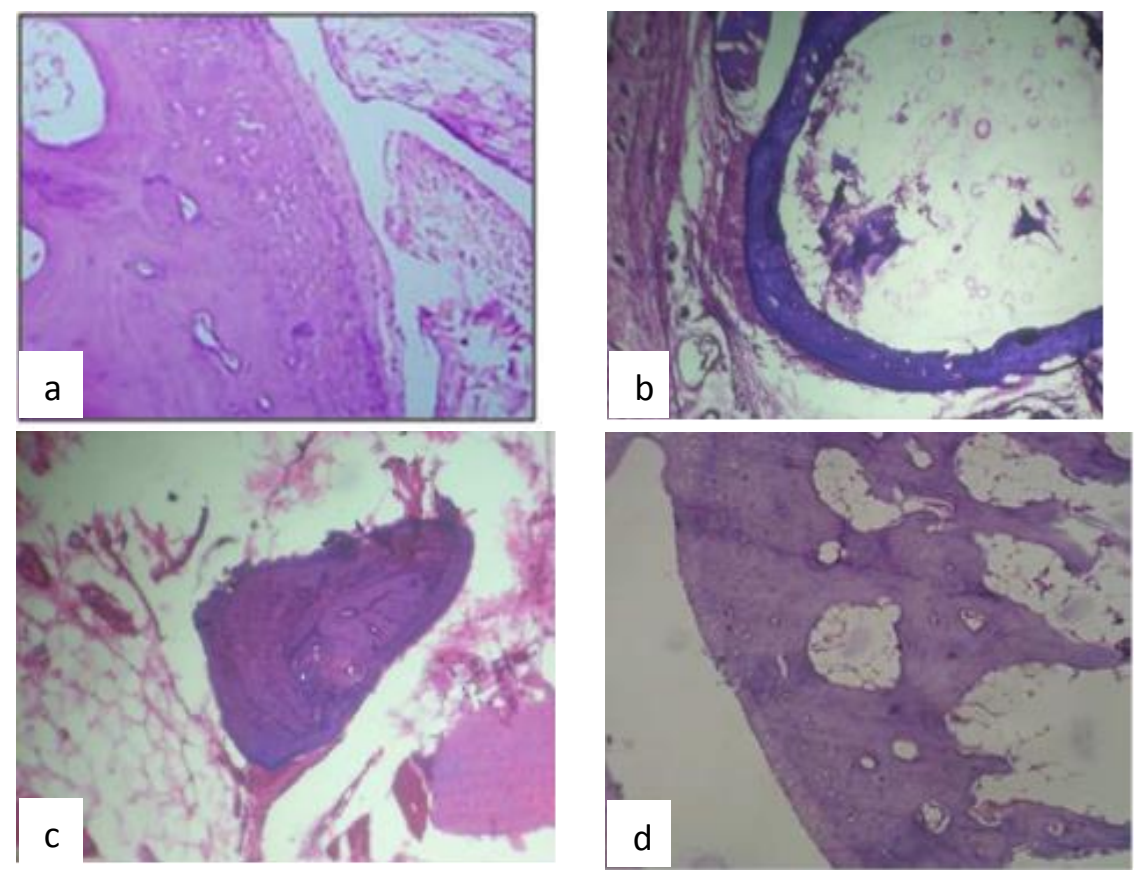

Fig. 2: a. normal with intact morphology of synovium and synovial lining. b. arthritic control, FA induced disease control rat the arrow mark showed plenty of lymphocytic infiltration in synovial lining with severe inflammation and marked angiogenesis studied with proliferation of synovial cells. c. Diclofenac treated $(50 \mathrm{mg} / \mathrm{kg})$ arrow mark showed significant protection with mild lymphocytic infiltration with no evidence of thickening of synovial lining and angiogenesis. d. Piper betle leaves extract high dose treated $(400 \mathrm{mg} / \mathrm{kg})$ the arrow mark showed milder lymphocytic infiltration with no evidence of thickening of synovial lining and angiogenesis. 


\section{Conclusion}

In present study, the preliminary phytochemical analysis confirmed the presence of alkaloids, carbohydrates, tannins, essential oils, flavonoids. It was reported that the plant containing flavonoids, alkaloids and other bioactive principles are responsible for anti arthritic activity. Hence it is revealed that the presence of flavonoids, alkaloids, etc in the Piper betle leaves extract might be responsible for its anti arthritic activity by suppressing the inflammation by inhibiting the proinflammatory mediators and probably by their antioxidant properties. From the results of current investigation, it is concluded that the hydro alcoholic extract of Piper betle leaves possesses potentially useful anti arthritic activity since it explored a positive result in controlling inflammation in adjuvant induced arthritic model in rats.

It is worthwhile to isolate the bioactive principles, which are responsible for these activities are in process. These findings justify the traditional use of this plant in the treatment of inflammatory and arthritic conditions, and validate its claim of being used for the said purpose in folklore medicine.

\section{Acknowledgement}

We acknowledge the Srinivas College of Pharmacy Mangalore for providing laboratory facilities to conduct the research work.

\section{References}

1. Goldring SR, Gravallese EM. Mechanisms of bone loss inflammatory arthritis: diagnosis and therapeutic implications. Arthritis Res. 2000;2(1):33-7.

2. Rehman Q, Lane NE. Bone loss therapeutic approaches for preventing bone loss in inflammatory arthritis. Arthritis Res. 2001;3 221-7.

3. Pathak N, Gohil P, Patel NB, Kasture S, Jivani N, Bhalodia Y. Curative effect of Albizzia lebbeck methanolic extract against arthritis-with reference to bone erosion. Int J Pharm Sci Res. 2000;1(3):183-7.

4. Mittal S, Dixit PK. In-vivo anti-inflammatory and antiarthritic activity of Asparagus racemosus roots. Int $\mathbf{J}$ Pharm Sci Res. 2013;4(7):2652-8.

5. Paschapur MS, Patil MB, Kumar R, Patil SR. Evaluation of anti-inflammatory activity of ethanolic extract of Borassus flabellifer L. male flowers (inflorescences) in experimental animals. J Med Plants Res. 2000;3(2):4954.

6. Sen S, Chakraborty R, De B, Ganesh T, Raghavendra HG, Debnath S. Analgesic and anti-inflammatory herbs: A potential source of modern medicine. Int J Pharm Sci Res. 2010;1(11):32-44.

7. Sekine C, Sugihara T, Miyake S. Successful treatment of animal models of rheumatoid arthritis with small molecule cyclin dependent kinase inhibitors. J Immunol. 2008;4(180):1954-61.

8. Singh S, Nair V, Gupta YK. Anti-arthritic activity of Majoon suranjan in rat. Indian J Med Res. 2011;134(3):384-8.

9. Amdekar S, Roy P, Singh V, Kumar A, Singh R, Sharma P. Anti-inflammatory activity of lactobacillus on carrageenan-induced paw edema in male Wistar rats. Int $\mathbf{J}$ Inflam. 2012: 1-6.
10. Sengupta R, Banik JK. A review on betel leaf (PAN). Int J Pharm Sci Res. 2000;4(12):4519-24.

11. Gumbhar CM, Patil SY, Yadav PS, Yadhav PH, Metkari VB. Prophylactic effect of hydro alcoholic extract of Colocasia esculanta leaves in CFA and formaldehyde induced arthritic rats. Asian J Pharm Sci Dev. 2014;2(1):52-9.

12. Rekha VPB, Kollipara M, Gupta S, Krishna YB, Pulicherla K. A Review on Piper betle L. Nat Prom Med Reserv. 2001;1(5):276-89.

13. Kore KJ, Shete RV. Anti-Arthritic activity of hydro alcoholic extracts Lawsonia Innermis against adjuvant arthritis. Int J Drug Dev Res. 2000;3(4):217-24.

14. Selvarani K, Viji SBG. Anti- arthritic activity of Cayratia pedata leaf extract in freund adjuvant induced arthritis rats. Int J Res Plant Sci. 2014;4(2):55-9.

15. Suleyman H, Demirezer LO, Kuruuzum A, Banoglu ZN, Gocer F, Ozabakir G, Gepdiremen A. Anti-inflammatory effect of the aqueous extract from Rumex patientia $\mathrm{L}$ roots. J Ethnopharmacol. 1991;65:141-8.

16. Ekambaram S, Perumal SS, Subramanian V. Evaluation of anti-arthritic activity of Strychnos potatorum linn seeds in freund adjuvant induced arthritic rat model. BMC Complement Altern Med. 2010;10(53):2-9. 